\title{
An Economic Analysis of Interest Rate Spread in the Commercial Bank of Bangladesh
}

\section{Muhammad Rabi Ullah*}

Department of Economics, Bangabandhu Sheikh Mujibur Rahman Science and Technology University (BSMRSTU), Gopalganj-8100, Bangladesh.

*Correspondence: rabiullah_ju@yahoo.com (Assistant Professor, Department of Economics, Bangabandhu Sheikh Mujibur Rahman Science and Technology University, Gopalganj-8100, Bangladesh).

\section{ABSTRACT}

This study aims to present the discussion on the Interest Rate Spread (IRS) of the commercial banks in Bangladesh perspective. This paper also explains the interest rate spread in the commercial bank's of Bangladesh using time series data of 60 banks covering the period of 1976 to 2020. The analysis shows that the higher the non-interest income as a ratio of total assets of a bank, the lower its spread. In this study, I tried to show the relationship among the lending interest rate with broad money, inflation, quasi money, official exchange rate, and personal remittance. Variables are using time series data. Here I used some proxy data of Bangladesh Bank based on the time series data from 1976-2020 periods from world development indicator and also collected data from various publications of Bangladesh Bank and other relative sources. In this paper, I used different statistical tools such as bar graph, pie chart, line bar, column, area, etc. The analyze the money supply and its effect on interest rate spread in Bangladesh and analyze the official exchange rate and trend on interest rate spread. Here shows the efficiency of the commercial banking sector and hence economic growth and development of Bangladesh.

Keywords: Broad money, Inflation, Bank rate, Commercial bank, Remittance, and Economic development.

\section{INTRODUCTION:}

A difference or spread between two related interest rates occurs in many types of business or finance transactions. As it relates to your business, a spread could be relevant if you are borrowing money or if your business involves lending or arranging for loans for your customers. However, there are alternative ways of measuring Interest Rate Spread (IRS) in the literature, the amount by which the interest earned by an investment exceeds or fails to exceed its own interest liability. If a bank pays depositors one interest rate, and lends the deposited money out at a higher interest rate, the difference between those two interest rates is the interest rate spread.

UniversePG I www.universepg.com
The scenario of interest rate spread of the banking system in 2021, January was 3.05 where bank rate was 4.00 and schedule banks weighted average deposits was 4.51 and advances 7.56. In the months of February, March, April, May and June was 3.04, 3.05, $3.04,3.26$ and 3.20 respectively. The last data of October 2021 where the schedule banks weighted average de-posits was 4.01 and advances 7.15 and the IRS was $(7.15-4.01)=3.14$. In 2020 the bank rate was 5.00 and IRS in January was 3.97 where the schedule banks weighted average deposits were 5.69 and advances 9.66. In the months of February, March, April, May and June was 4.09, 4.07, 2.92, 2.94 and 2.89 respectively. The last data of October 2021 where the 
schedule banks weighted average deposits was 4.01 and advances 7.15 and the IRS was $(7.15-4.01)=3.14$. In September of 2020 where the schedule banks weighted average deposits was 4.79 and advances 7.79 and the IRS was $(7.79-4.79)=3$. For any business that lends money, the interest rate spread is what the company charges on a loan compared to its cost of money. A bank runs on interest rate spreads, paying a certain rate on savings and $\mathrm{CD}$ deposits and making loans at higher rates than it pays to savers. Publicly traded financial companies such as banks often report the net interest rate spread earned on quarterly and annual financial reports. The World Bank supplies interest rate spread data from countries around the world showing the difference between the average lending rate and deposit rate. Interest rate spread (lending rat minus deposit rate; \%). Interest rate spread is the interest rate charged by banks on loans to prime customers minus the interest rate paid by commercial or similar banks for Demand, Time, or Savings deposits. This page has the latest recorded value, an historical data chart and related indicators for interest rate spread.

In banking, the net interest rate spread is the difference between interest earned on loans, securities, and other interest-earning assets and the interest paid on deposits and other interest-bearing liabilities. Intuitively, net interest rate spread is similar to profit margin. In general, the larger a bank's interest rate spread, the more it earns and the more it is therefore worth. When interest rates change, however, the interest a bank receives on its assets and pays on its liabilities fluctuates and can decrease income. Thus, it is important to monitor changes in net interest rate spreads as well as the size of those spreads. Interest rate spreads define, apart from reference interest rates, the markups and markdowns that can be stored in the system independent of the yield curve. They can be positive or negative. Interest spreads are managed in the system as follows: Create the required interest rate spread types in customizing. This enables interest rate spreads to be entered in the system automatically in the same way as it is entered manually for every combination of refer-ence interest rate and interest rate spread type. The money supply and its effect on interest rate spread in Bangladesh and analyze the official exchange rate and trend on interest rate spreads. Here shows the efficiency of the

UniversePG I www.universepg.com commercial banking sector and hence economic growth and development of Bangladesh. The analysis brings out several systemic actions and measures at the bank level to improve earnings and profitability of the banks which are sustainable tools of reducing the IRS.

\section{Objective of the Study}

The overall objective of this study is to analyze the level and trends in interest rates spreads and to document the key macroeconomic and market determinants of interest rate spreads in Bangladesh over the 19762020 period. The study has four specific objectives as outlined below:

1) To analyze the money supply and its effects on interest rate spread in Bangladesh.

2) To discuss the movement and trends for the interest rate spreads of the commercial banks in Bangladesh perspective.

3) To analyze the relationship among lending interest rate, broad money, inflation, quasi money, official ex-change rate and personal remittance.

\section{Banking Sector and IRS in Bangladesh}

\section{Commercial Bank}

A bank that offers services to the general public and to companies called commercial bank. In brief, a commercial bank is a financial institution which performs the functions of accepting deposits from the general public and giving loans for investment with the aim of earning profit. In fact, commercial banks, as their name suggests, axe profit-seeking institutions hat is they do banking business to earn profit. They generally finance trade and commerce with short-term loans.

They charge high rate of interest from the borrowers but pay much less rate of interest to their depositors with the result that the difference between the two rates of interest becomes the main source of profit of the banks. It is a financial institution that offers checking accounts, demand deposits, business and personal loans, savings vehicles and a variety of other related financial services commercial banks are owned by shareholders and are run for a profit, which is largely obtained by lending at rates higher than they pay their depositors. Commercial banking is different from investment banking, which primarily raises money for businesses, facilitates mergers or acquisitions, and works for institutional investor's. 


\section{Interest Rate Spread}

Based on Monthly Weighted Average Rate of Interest on Deposits and Advances.

\begin{tabular}{|c|c|c|c|c|c|c|c|c|c|c|c|c|}
\hline \multirow[b]{2}{*}{$\begin{array}{l}\text { SI } \\
\text { No }\end{array}$} & \multirow[b]{2}{*}{$\begin{array}{l}\text { Name of } \\
\text { Banks }\end{array}$} & \multicolumn{4}{|c|}{ Interest Rate Spread (Overall) } & \multicolumn{4}{|c|}{$\begin{array}{l}\text { Interest Rate Spread (Excl. Credit } \\
\text { Card) }\end{array}$} & \multicolumn{3}{|c|}{$\begin{array}{l}\text { Interest Rate Spread (Excl. } \\
\text { Consumer Finance \& Credit } \\
\text { Card) }\end{array}$} \\
\hline & & $\begin{array}{l}\text { W. Avg. } \\
\text { Deposits }\end{array}$ & \multicolumn{2}{|c|}{$\begin{array}{l}\text { W. Avg. } \\
\text { Advances }\end{array}$} & Spread & \multicolumn{2}{|c|}{$\begin{array}{l}\text { W. Avg. } \\
\text { Deposits }\end{array}$} & $\begin{array}{l}\text { W. Avg. } \\
\text { Advances }\end{array}$ & Spread & $\begin{array}{l}\text { W. Avg. } \\
\text { Deposits }\end{array}$ & $\begin{array}{l}\text { W. Avg. } \\
\text { Advances }\end{array}$ & Spread \\
\hline \multicolumn{13}{|c|}{ October, 2021} \\
\hline 1 & \multicolumn{3}{|c|}{ Agrani Bank Limited } & 3.96 & 7.33 & 3.37 & 3.96 & 7.33 & 3.37 & 3.96 & 7.34 & 3.38 \\
\hline 2 & \multicolumn{3}{|c|}{ Janata Bank Limited } & 4.64 & 5.20 & 0.56 & 4.64 & 5.20 & 0.56 & 4.64 & 5.20 & 0.56 \\
\hline 3 & \multicolumn{3}{|c|}{ Rupali Bank Limited } & 4.36 & 7.10 & 2.74 & 4.36 & 7.10 & 2.74 & 4.36 & 7.14 & 2.78 \\
\hline 4 & \multicolumn{3}{|c|}{ Sonali Bank Limited } & 3.31 & 5.95 & 2.64 & 3.31 & 5.95 & 2.64 & 3.31 & 5.38 & 2.07 \\
\hline 5 & \multicolumn{3}{|c|}{ BASIC Bank Limited } & 5.89 & 4.23 & -1.66 & 5.89 & 4.23 & -1.66 & 5.89 & 4.18 & -1.71 \\
\hline \multirow[t]{2}{*}{6} & \multicolumn{3}{|c|}{$\begin{array}{l}\text { Bangladesh Development } \\
\text { Bank Limited }\end{array}$} & 5.45 & 6.19 & 0.74 & 5.45 & 6.19 & 0.74 & 5.45 & 6.16 & 0.71 \\
\hline & \multicolumn{3}{|c|}{ State Owned Banks } & 4.06 & 6.18 & 2.12 & 4.06 & 6.18 & 2.12 & 4.06 & 6.02 & 1.96 \\
\hline 7 & \multicolumn{3}{|c|}{ Bangladesh Krishi Bank } & 5.30 & 6.98 & 1.68 & 5.30 & 6.98 & 1.68 & 5.30 & 6.98 & 1.68 \\
\hline 8 & \multicolumn{3}{|c|}{$\begin{array}{c}\text { Rajshahi Krishi Unnayan } \\
\text { Bank }\end{array}$} & 7.70 & 7.39 & -0.31 & 7.70 & 7.39 & -0.31 & 7.70 & 7.53 & -0.17 \\
\hline \multirow[t]{2}{*}{9} & \multicolumn{3}{|c|}{ Probashi Kollyan Bank } & 5.36 & 8.47 & 3.11 & 5.36 & 8.47 & 3.11 & 5.36 & 7.22 & 1.86 \\
\hline & \multicolumn{3}{|c|}{ Specialised Banks } & 5.62 & 7.09 & 1.47 & 5.62 & 7.09 & 1.47 & 5.62 & 7.06 & 1.44 \\
\hline 10 & \multicolumn{3}{|c|}{ Standard Chartered Bank } & 0.43 & 6.78 & 6.35 & 0.43 & 6.19 & 5.76 & 0.43 & 5.16 & 4.73 \\
\hline 11 & \multicolumn{3}{|c|}{ State Bank of India } & 2.32 & 7.11 & 4.79 & 2.32 & 7.11 & 4.79 & 2.32 & 7.11 & 4.79 \\
\hline 12 & \multicolumn{3}{|c|}{ Habib Bank Ltd. } & 3.65 & 5.68 & 2.03 & 3.65 & 5.68 & 2.03 & 3.65 & 5.69 & 2.04 \\
\hline 13 & \multicolumn{3}{|c|}{ Citibank N.A } & 0.11 & 3.74 & 3.63 & 0.11 & 3.74 & 3.63 & 0.11 & 3.74 & 3.63 \\
\hline 14 & \multicolumn{3}{|c|}{$\begin{array}{l}\text { Commercial Bank of } \\
\text { Ceylon Limited }\end{array}$} & 2.36 & 6.30 & 3.94 & 2.36 & 6.28 & 3.92 & 2.36 & 6.21 & 3.85 \\
\hline 15 & National & Bank of $\mathrm{Pa}$ & kistan & 1.97 & 0.01 & -1.96 & 1.97 & 0.01 & -1.96 & 1.97 & 0.01 & -1.96 \\
\hline 16 & & oori Bank & & 0.49 & 5.13 & 4.64 & 0.49 & 5.13 & 4.64 & 0.49 & 4.89 & 4.40 \\
\hline 17 & $\begin{array}{l}\text { The H } \\
\text { Shan } \\
\text { Corp }\end{array}$ & $\begin{array}{l}\text { ong Kong a } \\
\text { shai Bankir } \\
\text { oration. Lt }\end{array}$ & & 0.99 & 5.15 & 4.16 & 0.99 & 5.15 & 4.16 & 0.99 & 5.12 & 4.13 \\
\hline 18 & Bank A & -Falah Lin & ited & 1.99 & 6.31 & 4.32 & 1.99 & 6.31 & 4.32 & 1.99 & 6.31 & 4.32 \\
\hline & For & eign Banks & & 0.84 & 5.85 & 5.01 & 0.84 & 5.57 & 4.73 & 0.84 & 5.07 & 4.23 \\
\hline 19 & $\mathrm{AB} \mathrm{I}$ & ank Limite & & 4.93 & 7.08 & 2.15 & 4.93 & 7.04 & 2.11 & 4.93 & 7.03 & 2.10 \\
\hline 20 & Islami B & $\begin{array}{l}\text { ank Bangla } \\
\text { Ltd }\end{array}$ & desh & 3.62 & 6.69 & 3.07 & 3.62 & 6.70 & 3.08 & 3.62 & 6.81 & 3.19 \\
\hline 21 & Nation: & I Bank Lim & ited & 6.32 & 6.82 & 0.50 & 6.32 & 6.80 & 0.48 & 6.32 & 6.79 & 0.47 \\
\hline 22 & The $\mathrm{C}$ & ity Bank L & & 2.66 & 7.40 & 4.74 & 2.66 & 7.18 & 4.52 & 2.66 & 6.92 & 4.26 \\
\hline 23 & IFIC & 3ank Limit & & 4.46 & 8.33 & 3.87 & 4.46 & 8.33 & 3.87 & 4.46 & 8.19 & 3.73 \\
\hline 24 & United C & $\begin{array}{l}\text { ommercial } \\
\text { Cimited }\end{array}$ & Bank & 3.39 & 7.41 & 4.02 & 3.39 & 7.31 & 3.92 & 3.39 & 7.29 & 3.90 \\
\hline 25 & Pubali & Bank Limi & & 3.79 & 8.03 & 4.24 & 3.79 & 8.02 & 4.23 & 3.79 & 8.04 & 4.25 \\
\hline 26 & Uttara & Bank Limi & & 3.92 & 7.88 & 3.96 & 3.92 & 7.87 & 3.95 & 3.92 & 7.79 & 3.87 \\
\hline
\end{tabular}




\begin{tabular}{|c|c|c|c|c|c|c|c|c|c|c|}
\hline 27 & Shimanto Bank Limited & 3.46 & 8.92 & 5.46 & 3.46 & 8.86 & 5.40 & 3.46 & 8.84 & 5.38 \\
\hline 28 & Eastern Bank Limited & 3.03 & 7.36 & 4.33 & 3.03 & 7.05 & 4.02 & 3.03 & 6.95 & 3.92 \\
\hline 29 & $\begin{array}{c}\text { National Credit \& } \\
\text { Commerce Bank Ltd }\end{array}$ & 3.71 & 7.36 & 3.65 & 3.71 & 7.35 & 3.64 & 3.71 & 7.33 & 3.62 \\
\hline 30 & Prime Bank Ltd & 2.76 & 6.88 & 4.12 & 2.76 & 6.85 & 4.09 & 2.76 & 6.82 & 4.06 \\
\hline 31 & Southeast Bank Limited & 4.33 & 6.65 & 2.32 & 4.33 & 6.59 & 2.26 & 4.33 & 6.55 & 2.22 \\
\hline 32 & Dhaka Bank Limited & 4.23 & 7.14 & 2.91 & 4.23 & 7.10 & 2.87 & 4.23 & 7.11 & 2.88 \\
\hline 33 & $\begin{array}{l}\text { Al-Arafah Islami Bank } \\
\text { Limited }\end{array}$ & 4.17 & 6.99 & 2.82 & 4.17 & 6.99 & 2.82 & 4.17 & 6.99 & 2.82 \\
\hline 34 & Social Islami Bank Ltd. & 4.84 & 7.80 & 2.96 & 4.84 & 7.77 & 2.93 & 4.84 & 7.77 & 2.93 \\
\hline 35 & $\begin{array}{l}\text { Dutch-Bangla Bank } \\
\text { Limited }\end{array}$ & 1.72 & 7.59 & 5.87 & 1.72 & 7.49 & 5.77 & 1.72 & 7.39 & 5.67 \\
\hline 36 & Mercantile Bank Limited & 5.03 & 7.62 & 2.59 & 5.03 & 7.60 & 2.57 & 5.03 & 7.54 & 2.51 \\
\hline 37 & Standard Bank Limited & 4.42 & 7.71 & 3.29 & 4.42 & 7.71 & 3.29 & 4.42 & 7.82 & 3.40 \\
\hline 38 & One Bank Limited & 4.75 & 7.58 & 2.83 & 4.75 & 7.50 & 2.75 & 4.75 & 7.42 & 2.67 \\
\hline 39 & EXIM Bank Limited & 4.73 & 7.18 & 2.45 & 4.73 & 7.17 & 2.44 & 4.73 & 7.17 & 2.44 \\
\hline 40 & $\begin{array}{l}\text { Bangladesh Commerce } \\
\text { Bank Limited }\end{array}$ & 6.08 & 4.52 & -1.56 & 6.08 & 4.49 & -1.59 & 6.08 & 4.48 & -1.60 \\
\hline 41 & $\begin{array}{c}\text { Mutual Trust Bank } \\
\text { Limited }\end{array}$ & 4.23 & 7.61 & 3.38 & 4.23 & 7.44 & 3.21 & 4.23 & 7.34 & 3.11 \\
\hline 42 & Premier Bank Limited & 4.62 & 7.79 & 3.17 & 4.62 & 7.70 & 3.08 & 4.62 & 7.65 & 3.03 \\
\hline 43 & $\begin{array}{c}\text { First Security Islami Bank } \\
\text { Limited }\end{array}$ & 5.57 & 7.83 & 2.26 & 5.57 & 7.83 & 2.26 & 5.57 & 7.75 & 2.18 \\
\hline 44 & Bank Asia Limited & 3.54 & 7.57 & 4.03 & 3.54 & 7.41 & 3.87 & 3.54 & 7.26 & 3.72 \\
\hline 45 & Trust Bank Limited & 3.44 & 7.93 & 4.49 & 3.44 & 7.90 & 4.46 & 3.44 & 7.77 & 4.33 \\
\hline 46 & $\begin{array}{l}\text { Shahjalal Islami Bank } \\
\text { Limited }\end{array}$ & 3.09 & 7.06 & 3.97 & 3.09 & 7.05 & 3.96 & 3.09 & 7.01 & 3.92 \\
\hline 47 & Jamuna Bank Ltd & 4.45 & 7.39 & 2.94 & 4.45 & 7.34 & 2.89 & 4.45 & 7.26 & 2.81 \\
\hline 48 & BRAC Bank Limited & 2.30 & 7.89 & 5.59 & 2.30 & 7.66 & 5.36 & 2.30 & 7.70 & 5.40 \\
\hline 49 & $\begin{array}{l}\text { NRB Commercial Bank } \\
\text { Limited }\end{array}$ & 4.23 & 8.58 & 4.35 & 4.23 & 8.51 & 4.28 & 4.23 & 8.46 & 4.23 \\
\hline 50 & $\begin{array}{c}\text { South Bangla Agriculture } \\
\text { \& Commerce Bank } \\
\text { Limited }\end{array}$ & 5.48 & 8.67 & 3.19 & 5.48 & 8.63 & 3.15 & 5.48 & 8.65 & 3.17 \\
\hline 51 & Meghna Bank Limited & 5.66 & 8.02 & 2.36 & 5.66 & 7.91 & 2.25 & 5.66 & 7.90 & 2.24 \\
\hline 52 & Midland Bank Limited & 4.54 & 8.11 & 3.57 & 4.54 & 8.09 & 3.55 & 4.54 & 8.09 & 3.55 \\
\hline 53 & Padma Bank Limited & 7.55 & 4.81 & -2.74 & 7.55 & 4.81 & -2.74 & 7.55 & 4.78 & -2.77 \\
\hline 54 & Union Bank Limited & 6.36 & 9.10 & 2.74 & 6.36 & 9.10 & 2.74 & 6.36 & 9.11 & 2.75 \\
\hline 55 & NRB Bank Limited & 5.18 & 8.78 & 3.60 & 5.18 & 8.20 & 3.02 & 5.18 & 8.09 & 2.91 \\
\hline 56 & $\begin{array}{l}\text { Global Islami Bank } \\
\text { Limited }\end{array}$ & 6.92 & 8.82 & 1.90 & 6.92 & 8.82 & 1.90 & 6.92 & 8.83 & 1.91 \\
\hline 57 & Modhumoti Bank Limited & 5.22 & 8.33 & 3.11 & 5.22 & 8.30 & 3.08 & 5.22 & 8.27 & 3.05 \\
\hline 58 & ICB Islamic Bank Ltd. & 3.83 & 1.59 & -2.24 & 3.83 & 1.59 & -2.24 & 3.83 & 1.30 & -2.53 \\
\hline 59 & $\begin{array}{c}\text { Community Bank } \\
\text { Bangladesh Limited }\end{array}$ & 5.13 & 8.93 & 3.80 & 5.13 & 8.92 & 3.79 & 5.13 & 8.84 & 3.71 \\
\hline
\end{tabular}




\begin{tabular}{|c|c|c|c|c|c|c|c|c|c|c|}
\hline 60 & $\begin{array}{c}\text { Bengal Commercial Bank } \\
\text { Limited }\end{array}$ & 4.49 & 8.74 & 4.25 & 4.49 & 8.74 & 4.25 & 4.49 & 8.74 & 4.25 \\
\hline & $\begin{array}{c}\text { Private Banks } \\
\text { All Banks }\end{array}$ & 4.14 & 7.45 & 3.31 & 4.14 & 7.39 & 3.25 & 4.14 & 7.35 & 3.21 \\
\hline & 4.01 & 7.15 & 3.14 & 4.01 & 7.10 & 3.09 & 4.01 & 7.03 & 3.02 \\
\hline
\end{tabular}

Note: Interest Rate Spread (Excluding Consumer Finance \& Credit Card) available from July, 2016. Interest Rate Spread (Excluding Credit Card) available from August, 2020. Source: Statistics Department, Bangladesh Bank, Head Office.

\section{Literature Review}

Studies to find out the determinants of spread of interest rate have been focusing on some factors However; a brief review of empirical studies that were conducted previously to determine the determinants of the spread of interest rate is demonstrated. Lot of attention has given to discover the important determinants of Interest Rate Spread. Some theoretical and imperial literature has explored various determinants of interest rate spread including Exchange rate, money supply, price level, demand for money, supply of money, remittance, inflation, interest rate spread, etc. A study was conducted nationally and internationally about the IRS in the following. Gambarcorta, (2004) studies factors that explain cross-sectional differences in spread of interest rate of banks in Italy. The study included both the micro and macroeconomic variables and the variables are operating cost, credit risk, interest rate volatility, loan demand and impact of monetary policy reflected by changes in policy rate. The study revealed that short term interest rate react less to monetary policy rate changes. In addition, the long term interest rate does not also change as banks don't feel to change long term interest rate frequently. Bank size has not been found to be an influential factor to determine interest rate spread. The study of Gambarcorta also found a positive relationship between spread of interest rate and GDP and inflation.

Mannasoo, (2012) also studied the determinants of interest rate spread in Estonia. He divided the spread of interest rate into pure interest rate and the remaining part to be explained by the market structures, regulations and idiosyncratic factors of banking organizations. According to his study, money market volatility and bank risk attitude have impacts on the pure interest rate spread. Credit risk has been found to have minimal impacts on the interest rate spread. On the other hand, the higher bank liquidity has been found to cause of lower interest rate margins. Grenade, (2007) conducted UniversePG I www.universepg.com study to find out the determinants of spread of interest rate of commercial bank by using the annual panel data of commercial banks in the Eastern Caribbean Currency Union. The study model includes factors such as regulatory Variables (statutory minimum savings rate), market power, and non-performing loan ratio; operating cost (Hoque et al., 2020) depends on net operating income, liquidity risk and real GDP. According to the study, statutory minimum savings rate market power, credit risk; operating cost and GDP have a positive relationship with spread of interest rate. Siddiqui, (2012) studied the determinants of spread of interest rate in Pakistan by using annual panel data of 22 commercial banks. The variables of the study include the market share, administrative expenses, liquidity risk, credit risk, net interest income as a share of total income, and return on average assets. The study has found significant positive relationship between spread of interest rate and credit risk, administrative cost and return on assets. There have been a few studies on this topic in Bangladesh. Mustafa et al. (2009) have studied the determinants of spread of interest rate by using the profit maximization model that based on industrial organization approach. They have used panel data consist of 48 Banks from 2004 to 2008. The study revealed that, the higher noninterest income of a bank leads lowers the spread of interest rate. It also disclosed that interest rate is impacted significantly by reserve ratio, operating cost and market share of a bank. So, there is a space to work with some other variables to identify the determinants of spread of interest rate. Grenade, (2007) studied used panel data techniques to measure the relevance of micro and macro factors in determining commercial banks' interest rate spreads over the period.

Hainzet et al (2012) analyzed by used regression model presented that several bank characteristics such as capital, profitability and loans-to-assets ratio influence the size of spreads. They found that the deter- 
minants of spreads remained largely stable during the sample period and its variability increased slightly during the crisis. Rebei, (2014) examined that the determinants of bank interest rates including bank specific, banking sector, macroeconomic, and legal indicators. The results show that the scale of operation, overhead costs, concentration index, and some macroeconomic variables (i.e., monetary policy rates and real growth) significantly influence interest rate margins. Romero \& Rodríguez, (2011) examined that which factors determine the financial intermediation margin for Costa Rican banks for the period 1994-2011. Their exertion pays particular consideration to which of these factors can be influenced by the Central Bank of Costa Rica during its monetary policy C. Kiptui1, (2014) analyzed the role played by bank and industry-specific factors as well as macroeconomic variables in the determination of interest margins in Kenya's banking sector. There are some Bangladeshi studies have been published in context of interest rate determinants. Mujeri and Younus, (2009). This article used a bank profit maximization model based on empirical industrial organization approach to explain the interest rate spread (IRS). This study showed that the higher the noninterest income as a ratio of total assets of a bank, the lower its spread. The result of this article suggested several systemic actions and measures at the bank level to improve earnings and profitability of the banks which are sustainable tools of reducing the IRS. Afroze, (2013) studied to give an overall idea on the Interest Rate Spread (IRS) of the Commercial Banks in Bangladesh perspective which is Based on the empirical data for the period 1974-2011 drawn from various publications of Bangladesh Bank and other sources, the empirical findings of this study found statistically significant correlation between IRS and deposit rate but no correlation with the lending rate. Uddin et al. examined that both the increase and the decrease of inflation rate (General Price level) are like a two-side sharpened razor in an economy like Bangladesh. They both are unsafe for an economy. In their study, they emphasized on the significance of variables and availability of data because of which some important determinants like unemployment rate (Ut), remittance (Rmt) and oil price (PPt) have been ignored in main model. Chowdhury \& Hossain, (2014) conducted to analyze the determinants of exchange rates in Bangladesh economy for the UniversePG I www.universepg.com period of 1990 to 2011 using simple single equation linear regression model (SELRM). Their result included that inflation rate, GDP growth rate, interest rate and current account balance has positive impact on exchange rate and the major role played by GDP. Rahman et al, ( 2015) attempted to investigate capital strength, credit risk, ownership structure, bank size, non-interest income, cost efficiency, off-balance sheet activities, liquidity as potential bank specific determinants as well as growth in gross domestic products, inflation as potential macroeconomic determinants of bank profitability by taking 25 commercial banks from Bangladesh for a period ranges from 2006 to 2013. Younus, (2014) examined the determinants of the CPI inflation in Bangladesh mostly the impact of the exchange rate through import prices and some macroeconomic variables on the price level during the post floating exchange rate regime. Chowdhury \& Ahmed (2009) analyzed the development and growth of Selected Private Commercial Banks of Bangladesh The r2 of branches, deposits and net income is more than 0.5. It indicates the prospect of private commercial banks in Bangladesh is very bright.

\section{METHODOLOGY:}

The main part of analysis variables is analytical part that shows the trend analysis using different statistical methods such as pie chart, column, line, bar diagram etc. In this part, researcher analyzed secondary data by using different statistical tools. Here, the researcher had done graphical analysis. Here researcher used secondary data of Bangladesh Bank based on the time series data from 1976-2018 periods from world development indicator, various publications of Bangladesh Bank and other sources.

\section{Research Variables}

Lending Interest Rate - An interest rate is the cost of borrowing money, or conversely, the income earned from lending money. Interest rates are expressed as percentage of the principal per period. He formula to find an interest rate of a loan is -

\section{Interest rate $=($ Total Repayment Amount - Amount Borrowed)/(Amount Borrowed)}

Let's assume XYZ Company is considering building a new $\$ 50$ mil-lion factory. If a bank agrees to lend XYZ the $\$ 50$ million dollars but requires $\mathrm{XYZ}$ to pay back 
$\$ 55$ mil-lion at the end of the year, we can calculate that $\mathrm{XYZ}$ will pay $\$ 5$ million $(\$ 55$ million repaid - $\$ 50$ million principal) to borrow the money. This translates to -

\section{Interest rate $=(\$ 5$ million $) /(\$ 50$ million $)=10 \%$ interest}

Quasi Money - Quasi-money is a term used in economics to describe highly liquid assets that can easily be converted into cash. In briefly, it describes highly liquid assets other than cash that can be quickly exchanged for cash. Examples of quasi money would include bank account balances, savings accounts, money fund, bank time deposits, certificates of deposit certificates of deposit and U.S. Treasury Bills. The amount of quasi money in an economic is often used by central bankers, economists and fundamental traders to compute the current level of the money supply in a country also called near money.

Broad Money - Broad money is the definition of the money supply which includes a wider scope for the definition of money. In economics, broad money is a measure of the money supply that includes more than just physical money such as currency and coins. Broad money includes notes and coins but also saving accounts and deposits in savings account. Broad money can also include treasury bills and gilts. These financial secure-ties are seen as near money broad money includes $\mathrm{M}_{2}, \mathrm{M}_{3}, \mathrm{M}_{4}, \mathrm{M}_{4}$ growth has been weak. One measure of the money supply that includes $\mathrm{m}_{1}$ plus savings and small time deposits, overnight repos at com-mercial banks and non institutional money market accounts.

Personal Remittance - A remittance is a transfer of money by a foreign worker to an individual in his or her home country. Money sent home by migrants competes with international aid as one of the largest financial inflows to developing countries. It also described personal remittances is sum of personal transfer and compensation of employees. Personal transfer a new item in the balance of payments manual $6^{\text {th }}$ edition (BPM), Workers' remittances are a significant part of international capital flows, especially with regard to labor-exporting countries.

UniversePG I www.universepg.com
Official Exchange Rate - An exchange rate which is imposed by the government called official exchange rate. Fixed exchange rate is the rate which is officially fixed by the government or monetary authority and not determined by market forces. Only a very small deviation from this fixed value is possible. In this system, foreign central banks stand ready to buy and sell their currencies at a fixed price. A typical kind of this system was used under Gold Standard System in which each country committed itself to convert freely its currency into gold at a fixed price.

Inflation - Inflation is the rate at which prices rise and purchasing power falls. It is why something that cost $\$ 1$ in 1980 cost \$2.37 in 2005. Two general theories explain inflation. The first, the demand-pull theory, says that prices increase when demand for goods and services exceeds their supply. The second, the costpush theory, says that companies create inflation when they raise their prices to cover higher supply prices and maintain margins. Inflation's fundamental relationship with supply and demand means that inflation directly or indirectly affects nearly every financial decision, from consumer choices to lending rates and from asset allocation to stock prices.

Growth Rate - The economy's above outlined growth track record is evidence enough that the financial sector has overall played its due role in mobilizing savings resources and allocating these to meet financing needs of the economy in ascending pace of sustained growth and structural transformation. Bangladesh's financial market structure developing as interlinked chain of intermediaries focused on specific market segments makes for better responsiveness to needs specific to the various market segments.

\section{RESULTS AND DISCUSSION:}

Trend Analysis - From the Table 1 and Fig. 1, during the period of 1976 to 2018 , it can be seen that, the lending interest rate was not change at 0.874591 during 1976 to 1980 but after that periods it was increased in 1982 and same as 1984 and in 1986 it was 1.017896 up to 1992 but it was again decreased till 1999 at 0.973784 . This ups and down situation was continue in the year 2018. So in lending interest rates in Bangladesh banking sector graph was showed an ups and down or fluctuation situation. 
Table 1: The trend of total Lending Interest Rate (Ir), Quasi Money (mq), Broad Money (bm), Personal Remittance (prc), Official Exchange Rate (oer), Inflation (i) in Bangladesh.

\begin{tabular}{|c|c|c|c|c|c|c|}
\hline Year & ln Ir & $\ln \mathbf{m q}$ & ln bm & In pre & In oer & $\ln i$ \\
\hline 1976 & 0.874591 & 0.890028 & 3.159785 & 2.818237 & 1.00588 & 1.054182 \\
\hline 1977 & 0.874591 & 0.97723 & 3.168894 & 2.900508 & 1.005308 & 0.153853 \\
\hline 1978 & 0.874591 & 0.953295 & 3.178668 & 2.921236 & 0.996625 & 1.176601 \\
\hline 1979 & 0.874591 & 0.967867 & 3.1871 & 2.942225 & 1.009484 & 0.928565 \\
\hline 1980 & 0.886964 & 0.9757 & 3.194939 & 2.977595 & 1.007181 & 1.052688 \\
\hline 1981 & 0.910235 & 0.972388 & 3.201286 & 2.983581 & 1.061129 & 0.829424 \\
\hline 1982 & 0.910235 & 0.971976 & 3.205917 & 2.999809 & 1.130236 & 0.827705 \\
\hline 1983 & 0.910235 & 1.051705 & 3.219557 & 3.009671 & 1.164204 & 0.760163 \\
\hline 1984 & 0.910235 & 1.114974 & 3.23186 & 2.997312 & 1.17339 & 0.724532 \\
\hline 1985 & 0.910235 & 1.090295 & 3.236911 & 2.997483 & 1.203576 & 1.070729 \\
\hline 1986 & 0.970422 & 1.10047 & 3.242811 & 3.004301 & 1.228081 & 0.747042 \\
\hline 1987 & 1.019781 & 1.110367 & 3.249519 & 3.017135 & 1.23325 & 0.879092 \\
\hline 1988 & 1.019781 & 1.120813 & 3.254474 & 3.018158 & 1.240507 & 0.700295 \\
\hline 1989 & 1.019781 & 1.141092 & 3.261049 & 3.017795 & 1.245346 & 0.751803 \\
\hline 1990 & 1.019781 & 1.13499 & 3.264836 & 3.019124 & 1.26496 & 0.629582 \\
\hline 1991 & 1.017896 & 1.156383 & 3.269732 & 3.018524 & 1.280918 & 0.004122 \\
\hline 1992 & 0.996229 & 1.167382 & 3.274043 & 3.026789 & 1.298091 & -0.05274 \\
\hline 1993 & 0.996229 & 1.18355 & 3.27782 & 3.031612 & 1.30237 & 0.621109 \\
\hline 1994 & 0.983631 & 1.21362 & 3.284463 & 3.038015 & 1.306753 & 0.320497 \\
\hline 1995 & 0.970422 & 1.212341 & 3.288749 & 3.040083 & 1.307201 & 0.676207 \\
\hline 1996 & 0.970422 & 1.176781 & 3.292545 & 3.045446 & 1.317147 & 1.082465 \\
\hline 1997 & 0.970422 & 1.180397 & 3.295994 & 3.051462 & 1.330183 & 0.288978 \\
\hline 1998 & 0.970422 & 1.183872 & 3.299988 & 3.053863 & 1.347589 & 0.441628 \\
\hline 1999 & 0.973784 & 1.2024 & 3.30528 & 3.059403 & 1.359324 & 0.285178 \\
\hline 2000 & 1.008264 & 1.229493 & 3.311748 & 3.063393 & 1.374719 & 0.213017 \\
\hline 2001 & 1.015998 & 1.306446 & 3.324701 & 3.066534 & 1.391753 & 0.167278 \\
\hline 2002 & 1.019781 & 1.32251 & 3.329562 & 3.080689 & 1.400816 & 0.306857 \\
\hline 2003 & 1.019781 & 1.330173 & 3.334264 & 3.085747 & 1.401928 & 0.565644 \\
\hline 2004 & 0.990003 & 1.339828 & 3.338964 & 3.091029 & 1.407613 & 0.417256 \\
\hline 2005 & 0.970422 & 1.349936 & 3.344158 & 3.102724 & 1.426473 & 0.420739 \\
\hline 2006 & 1.004312 & 1.366046 & 3.350634 & 3.109719 & 1.442944 & 0.571472 \\
\hline 2007 & 1.019781 & 1.365069 & 3.355079 & 3.118154 & 1.442744 & 0.624528 \\
\hline 2008 & 1.028102 & 1.369668 & 3.360369 & 3.131742 & 1.441792 & 0.723633 \\
\hline 2009 & 0.986198 & 1.387267 & 3.366749 & 3.138819 & 1.443306 & 0.647976 \\
\hline 2010 & 0.941939 & 1.404139 & 3.373327 & 3.140155 & 1.445382 & 0.676186 \\
\hline 2011 & 0.949338 & 1.408539 & 3.378669 & 3.144759 & 1.460038 & 0.723539 \\
\hline 2012 & 0.941939 & 1.412328 & 3.384011 & 3.151489 & 1.48275 & 0.741846 \\
\hline 2013 & 0.941939 & 1.414972 & 3.388695 & 3.150716 & 1.47202 & 0.678337 \\
\hline 2014 & 0.941939 & 1.421981 & 3.393505 & 3.154025 & 1.470659 & 0.55099 \\
\hline 2015 & 0.931938 & 1.414927 & 3.351059 & 3.140519 & 1.460695 & 0.56087 \\
\hline 2016 & 0.942949 & 1.385291 & 3.366719 & 3.149216 & 1.486281 & 0.68324 \\
\hline 2017 & 1.019743 & 1.415928 & 3.371902 & 3.151978 & 1.390534 & 0.59176 \\
\hline 2018 & 0.913919 & 1.421798 & 3.387501 & 3.154591 & 1.457029 & 0.56291 \\
\hline
\end{tabular}




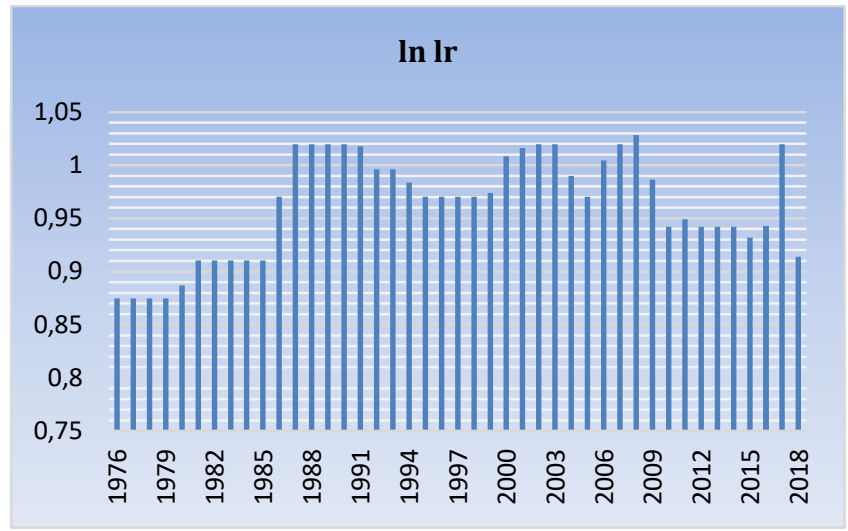

Fig. 1: Historical Trends of Lending Interest Rates (Ir) in Bangladeshi Banking Sector from 1976 to 2018.

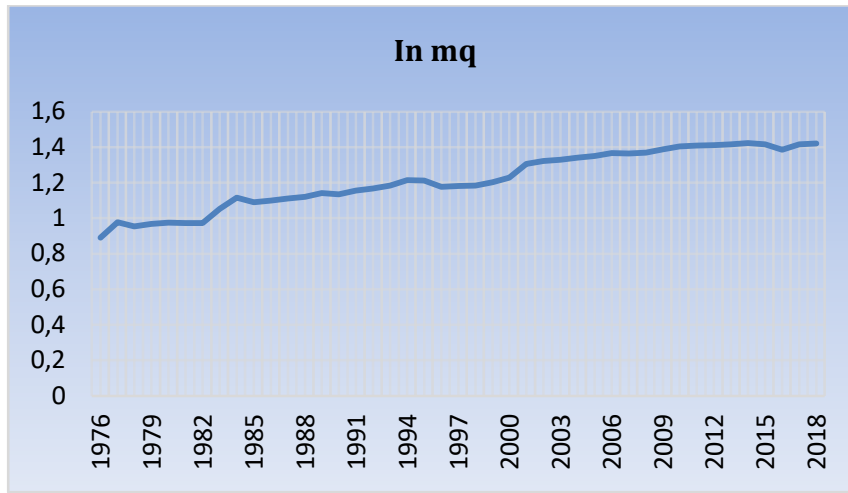

Fig. 2: Historical Trends of Quasi Money in Bangladesh Banking Sector from 1976 to 2018.

From the Table 1, author draws the figure two. In this line shows the historical trends of quasi money during the period of 1976 to 2018 . Here shows that, the quasi money trend line was increased slowly but in the year of 1985 decreased at 1.090295 but again it increased in 2000. It is again little increased and continue raised day by day in 2016 at the rate 1.421981 . There is also an increasing trend after 2016 to 2018.

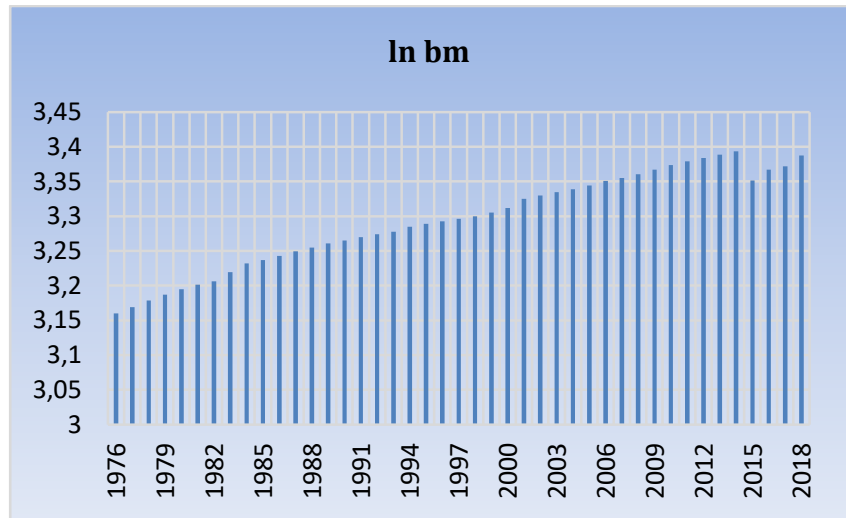

Fig. 3: Historical Trends of Broad Money in

Bangladesh Banking Sector from1976 to 2018.

UniversePG I www.universepg.com
Fig. 3 shows the bar graph of historical trend of broad money during the period of 1976 to 2018. It can be seen that the broad money trend line was increased day by day upto1995 and then decreased in 1996 to 2001. After 2002 it was increased at the level of 3.393505 up to 2014. Then we can see that there is an increasing trend line up to 2018.

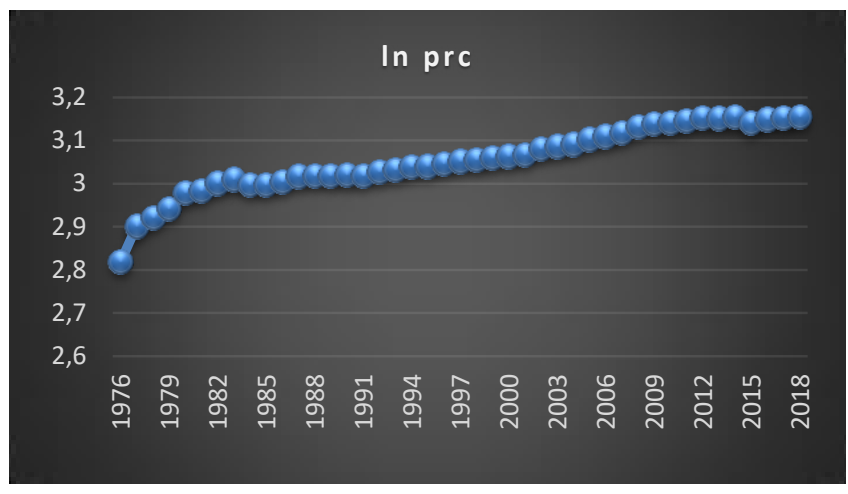

Fig. 4: Historical Trends of Personal Remittance in Bangladesh Banking Sector from 1976 to 2018.

Using the Table 1, draw the Fig. 4 that shows the historical trend of personal remittance in Bangladesh. Here we see that the personal remittance was increased in the year of 1976 to 1982 from 2.818237 to 3.009671 but it again decreased up to 1986 and after two years it decreased and trend line displayed upward from 1989 at 3.004301 and then day by day it increased at 3.1540 25 in 2014. There was a constant trend line up to 2018.

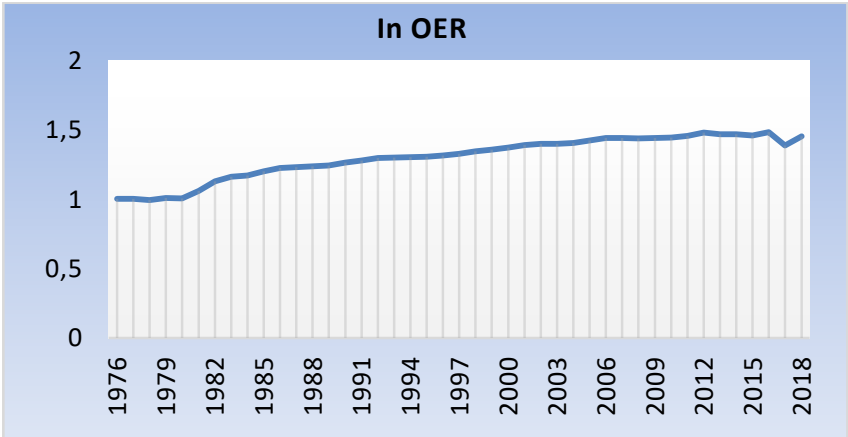

Fig. 5: Historical Trends of Official Exchange Rate in Bangladesh Banking Sector from1976 to 2018.

From the Table 1 and Fig. 5, during the period of 1976 to 2018 , it can be seen that the official exchange rate was constant I n 1976 to 1980 but in the year of 1982 it was increased at 1.130236 but after that it also increased and continue raised day by day up to 2016 . In 2017 it again fall and then increasing trend up to 2018. 


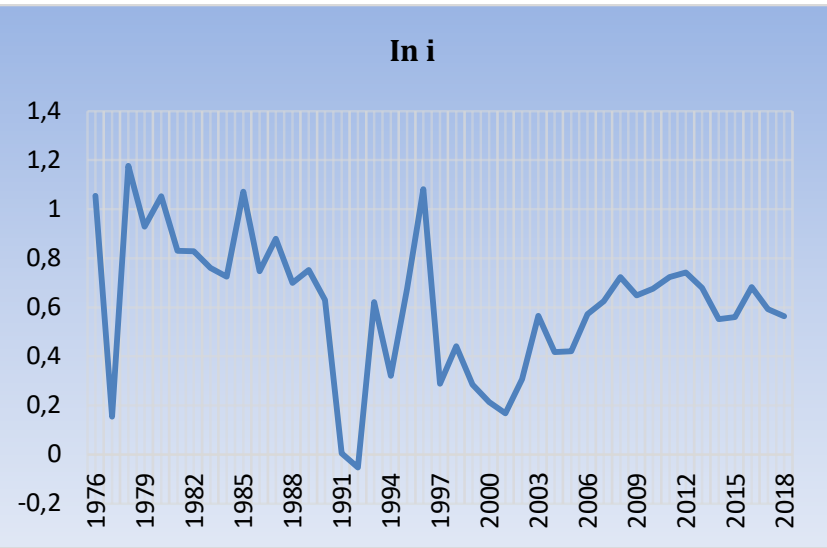

Fig. 6: Historical Trends of Inflation in Bangladesh Banking Sector from 1976 to 2018.

Lastly, Fig. 6 introduced the historical trend of inflation in Bangladesh banking sector perspective during the period of 1976 to 2018. This Fig shows that the inflation rate was 1.054182 in 1976 and fall it in the year of 1977 at 0.153853 but again it rose in 1978 at 1.176601. After that it again falls till 1984 at $0.724-$ 532. The ups and down situation was continuing and also has a negative value in 1992 at -0.05274 . The fluctuation is continuing during the year 1993 to 2002 at decreasing level. After that it was also an increasing trend line up to 2016 and decreased in 2018.

\section{CONCLUSION AND RECOMMENDATIONS:}

The study identifies several determinants underlying the determination of IRS in the commercial banking sector in Bangladesh. Banks are formed to ensure smoother financial activities of the country's economy. From the beginning people trust on the banking activities as well as their rules and regulation and keep their money for safety and security. In this study researcher tried to show the relationship between the lending interest rate and broad money, lending interest rate and inflation, lending interest rate and quasi money and, lending interest and increase official exchange rate, lending interest rate and personal remittance variables using time series data. In this study tried to find the relationship between these variables that the increasing in the lending interest rate can change the broad money, inflation, quasi money, official exchange rate and personal remittance. There is some limitation in this paper. Commercial banking sector is a big issue and it is difficult to collect primary data. So researcher only depends on secondary data source. But because of limited data of current exUniversePG I www.universepg.com change rate, economic growth, function of commercial bank, researcher faces some problem and use proxy data. If researcher could collect proper data of banking sector, then this work would have been better from now. After analyzing the performance of the commercial banks of Bangladesh we can conclude the following points. Overall interest rate spread in the country's banking sector increased slightly in March as the commercial banks have slashed their interest rates on deposit more than that of leading rates, bankers said. The weighted average spread between lending and deposit rates offered by the banks rose to 4.86 per cent in March 2016 from 4.81 per cent in the previous month, according to the central bank latest statistics. It was 4.84 per cent in January 2016. To address these issues appropriate macro-policies, especially fiscal, monetary and trade policies combined with a set of heterodox policies, backed by political will and political stability (with democratic norms, rule of law and good governance), are necessary to enable the Bangladeshi economy to grow at an accelerated rate in the medium term and pave the way for Bangladesh to become a "success story" of overall development.

\section{ACKNOWLEDGEMENT:}

To being, I wish to thank Almighty Allah for keeping me to carry out this article and also I would like to thank to my colleagues who gives me their valuable suggestions in writing this article as well as all individuals who contributed directly or indirectly to the study's preparation, are acknowledged.

\section{CONFLICTS OF INTEREST:}

The author declares have no conflicts of interest in publishing this article.

\section{REFERENCES:}

1) Afroze, (2013) "Interest Rate Spread of Commercial Banks Empirical Evidence from Bangladesh" ASA University Review, 7(2).

2) Alam QN., (2020). Impacts of macroeconomic variables on the stock market returns of South Asian region, Can. J. Bus. Inf. Stud., 2(2), 24-34. https://doi.org/10.34104/cjbis.020.24034

3) Allen, L., (1988). The Determinants of Bank Interest Margins: A Note. The Journal of Financial and Quantitative Analysis, 23(2), p.231. https://doi.org/10.2307/2330883 
4) Chowdhury and Hossain, (2014). "Determinants of Exchange Rate in Bangladesh" Journal of Economics and Sustainable Development. , 5(1).

5) Grenade, K. H. I., (2007). Determinants of Commercial Banks Interest Rate Spreads: Some Empirical Evidence from the Eastern Caribbean Currency Union. Eastern Caribbean Central Bank Staff, Research Paper No. WP/ 07/01.

6) Gambacorta, L., (2004). How banks set interest Rate? National Bureau of Economic Research, Working Paper 10295, Cambridge, MA 02138, Pp. 1-39.

https://core.ac.uk/download/pdf/6819843.pdf

7) Islam \& Rahman, (2014) "A Comparative Analysis of Interest Rate Spread in the Banking System" Chief Economist's Unit (CEU) Bangladesh Bank. Working Paper Series: WP 1407. Head Office, Dhaka, Bangladesh.

8) Mujeri M. K. \& Younus, (2009) “An Analysis of Interest Rate Spread in the Banking Sector in Bangladesh" The Bangladesh Development Studies, 32(4).

9) Mannasoo, K., (2012). Determinants of Bank Interest Spread in Estonia, EESTIPANK, and Working Paper No. 1/2012.

https://www.researchgate.net/publication/3228317 $\underline{81}$

10) Mustafa K. Mujeri, and Sayera Younus, (2009). An Analysis of Interest Rate Spread in the Bank- ing Sector in Bangladesh. The Bangladesh Development Studies, 32(4), 1- 34.

https://ideas.repec.org/a/ris/badest/0487.html

11) Maureen Were, and Joseph Wambua, (2013). Assessing the determinants of interest rate spread of commercial banks in Kenya: An empirical investigation, KBA centre for research on financial market and policy. Working paper series, 4, Pp. 1-28.

https://www.kba.co.ke/downloads/Working_P\%20 aper_WPS_04_12\%5B2\%5D.pdf

12) Rebei. N., (2014). "Determinants of Interest Rate Spreads in Solomon Islands" IMF Working Paper Institute for Capacity Development. Department Authorized for distribution by Ray Brooks WP/14/105.

13) Rahman et al., (2015). "Determinants of Bank Profitability: Empirical Evidence from Bangladesh" Published by Canadian Center of Science and Education135. International Journal of Business and Management; 10(8), 2015 ISSN 1833-3850 E-ISSN 1833-8119

14) Siddiqui M. A., (2012). Towards Determination of Interest Spread of Commercial Banks: Empirical Evidences from Pakistan. African Journal of Business Management, 6(5), pp. 1851-1862. https://doi.org/10.5897/AJBM10.929

Citation: Ullah MR. (2022). An economic analysis of interest rate spread in the commercial bank of Bangladesh. Can. J. Bus. Inf. Stud., 4(1), 01-11. https://doi.org/10.34104/cjbis.022.01011 @ @ 